\title{
The Immediate Early Gene Arc Is Not Required for Hippocampal Long-Term Potentiation
}

\author{
${ }^{\circledR}$ Madeleine Kyrke-Smith, ${ }^{1}$ Lenora J. Volk, ${ }^{2,3}$ Samuel F. Cooke, ${ }^{4,5,6}{ }^{\oplus}$ Mark F. Bear, ${ }^{4}{ }^{\oplus}$ Richard L. Huganir, ${ }^{2}$ and \\ ${ }^{\circ}$ Jason D. Shepherd ${ }^{1 \star}$ \\ ${ }^{1}$ Department of Neurobiology, University of Utah, Salt Lake City, Utah 84112, ${ }^{2}$ Department of Neuroscience, The Johns Hopkins School of \\ Medicine, Baltimore, Maryland 21205, ${ }^{3}$ Department of Neuroscience, University of Texas Southwestern Medical Center, Dallas, Texas 75390, ${ }^{4}$ The \\ Picower Institute for Learning and Memory, Massachusetts Institute of Technology, Cambridge, Massachusetts 02139, ${ }^{5}$ Department of Basic and \\ Clinical Neurosciences, King's College London, London, WC2R 2LS, United Kingdom, and ${ }^{6}$ MRC Centre for Neurodevelopmental Disorders, King's \\ College London, London, SE1 1UL, United Kingdom
}

Memory consolidation is thought to occur through protein synthesis-dependent synaptic plasticity mechanisms such as longterm potentiation (LTP). Dynamic changes in gene expression and epigenetic modifications underlie the maintenance of LTP. Similar mechanisms may mediate the storage of memory. Key plasticity genes, such as the immediate early gene Arc, are induced by learning and by LTP induction. Mice that lack Arc have severe deficits in memory consolidation, and Arc has been implicated in numerous other forms of synaptic plasticity, including long-term depression and cell-to-cell signaling. Here, we take a comprehensive approach to determine if Arc is necessary for hippocampal LTP in male and female mice. Using a variety of Arc knock-out (KO) lines, we found that germline Arc KO mice show no deficits in CA1 LTP induced by high-frequency stimulation and enhanced LTP induced by theta-burst stimulation. Temporally restricting the removal of Arc to adult animals and spatially restricting it to the CA1 using Arc conditional $\mathrm{KO}$ mice did not have an effect on any form of LTP. Similarly, acute application of Arc antisense oligodeoxynucleotides had no effect on hippocampal CA1 LTP. Finally, the maintenance of in vivo LTP in the dentate gyrus of Arc KO mice was normal. We conclude that Arc is not necessary for hippocampal LTP and may mediate memory consolidation through alternative mechanisms.

Key words: Arc; hippocampus; LTP; memory; synaptic plasticity

Significance Statement

The immediate early gene Arc is critical for maintenance of long-term memory. How Arc mediates this process remains unclear, but it has been proposed to sustain Hebbian synaptic potentiation, which is a key component of memory encoding. This form of plasticity is modeled experimentally by induction of LTP, which increases Arc mRNA and protein expression. However, mechanistic data implicates Arc in the endocytosis of AMPA-type glutamate receptors and the weakening of synapses. Here, we took a comprehensive approach to determine if Arc is necessary for hippocampal LTP. We find that Arc is not required for LTP maintenance and may regulate memory storage through alternative mechanisms.

Received Jan. 2, 2020; revised Mar. 25, 2021; accepted Mar. 30, 2021.

Author contributions: M.K.-S., L.J.V., S.F.C., M.F.B., R.L.H., and J.D.S. designed research; M.K.-S., L.J.V., and S.F.C. performed research; M.K.-S., L.J.V., and S.F.C. analyzed data; M.K.-S and J.D.S. wrote the paper.

M.K.-S. was supported by a National Alliance for Research on Schizophrenia and Depression Young Investigator Grant from the Brain and Behavioral Research Foundation, sponsored by the Osterhaus Family as the Jeanne Marie Lee Investigator. This work was supported by the Howard Hughes Medical Institute (M.F.B. and R.L.H.), and the National Institutes of Health (R01MH112766 to J.D.S.). We thank Dr. Richard Palmiter (University of Washington) for the conditional Arc KO mice and Dr. Paul Worley (The Johns Hopkins University) for the $\operatorname{Arc}^{-1-}$ line.

The authors declare no competing financial interests.

Correspondence should be addressed to Jason D. Shepherd at Jason.Shepherd@neuro.utah.edu.

https://doi.org/10.1523/JNEUROSCI.0008-20.2021

Copyright $\odot 2021$ the authors

\section{Introduction}

The maintenance of memory and Hebbian forms of synaptic plasticity, such as long-term potentiation (LTP) and long-term depression (LTD), requires activity-dependent gene expression and de novo protein synthesis (Goelet et al., 1986; Bliss and Collingridge, 1993; Abraham and Williams, 2003; Takeuchi et al., 2014 Poo et al., 2016; Choi et al., 2018; Kyrke-Smith and Williams, 2018). The molecular underpinnings of LTP, in particular, are of interest because of the overlap in activity-induced genes critically involved in both LTP and memory (Alberini, 1999; 2009; Kandel et al., 2014). Thus, identifying genes that are necessary for the maintenance of LTP may be key to identifying memory molecules. The immediate early gene Arc is induced by neuronal activity, is necessary for memory consolidation (Guzowski et al., 2000; Plath et al., 2006; Ploski et al., 2008), and 
is implicated in various forms of synaptic plasticity (Shepherd and Bear, 2011). Arc mRNA expression is increased in the dentate gyrus (DG) of the hippocampus after seizure or LTP induction (Link et al., 1995; Lyford et al., 1995), some of which moves out of the cell body and into dendrites where it localizes near potentiated synapses (Steward et al., 1998; Yin et al., 2002; Moga et al., 2004; Rodríguez et al., 2005). LTP maintenance has been shown to be attenuated by application of antisense RNA against Arc in rats (Guzowski et al., 2000; Messaoudi et al., 2007) and in Arc knock-out (KO) mice under urethane anesthesia (Plath et al., 2006). However, Arc is also critical for the maintenance of hippocampal LTD (Plath et al., 2006; Waung et al., 2008) and for homeostatic scaling of the AMPA-type glutamate receptors (i.e., AMPARs; Shepherd et al., 2006, Korb et al., 2013). How one protein can be critical for both increases and decreases in synaptic strength has remained an open question.

Arc interacts with the endocytic machinery at synapses, such as clathrin-adaptor protein 2 (AP-2; DaSilva et al., 2016), dynamin, and endophilin (Chowdhury et al., 2006). Acute overexpression of Arc leads to the endocytosis of AMPARs, thereby decreasing synaptic strength (Rial Verde et al., 2006; Shepherd, Rumbaugh et al., 2006). Arc also interacts with the calcium/calmodulin-dependent protein kinase II- $\beta$ (CaMKII $\beta$ ) isoform to decrease synaptic strength at inactive synapses (Okuno et al., 2012). However, Arc can also interact with drebrin, A, which may lead to F-Actin stabilization and the enlargement of dendritic spines, indicative of increased synaptic strength (Messaoudi et al., 2007; Bramham et al., 2010; Nair et al., 2017). Further, other Arc protein interactions raise the possibility that Arc may facilitate memory through mechanisms other than direct regulation of synaptic strength. For example, Arc protein may be found in the nucleus where it interacts with the nuclear spectrin isoform $\beta$ SpIV $\Sigma 5$ (Bloomer et al., 2007) and the histone acetyl-transferase Tip60 (Wee et al., 2014). Additionally, we recently found that Arc can form virus-like capsids that can encapsidate RNA and transfer Arc mRNA between cells (Pastuzyn et al., 2018).

Given the extensive literature implicating LTP as a cellular correlate of memory (Bliss and Collingridge, 1993; Abraham and Williams, 2003; Whitlock et al., 2006; Rioult-Pedotti et al., 2007; Takeuchi et al., 2013; Nabavi et al., 2014; Poo et al., 2016; Choi et al., 2018), we aimed to comprehensively investigate whether Arc is required for the maintenance of hippocampal LTP. We used two different Arc KO mouse lines and an Arc conditional KO $\left(A \mathrm{Al}^{\mathrm{fl} / \mathrm{fl}}\right)$ floxed line for both in vitro and in vivo LTP analysis. We find that Arc is not required for the maintenance of LTP, using multiple LTP induction protocols in these mice. Additionally, acute application of Arc antisense oligodeoxynucleotides (ODNs) that have been previously used for in vivo experiments in the DG (Messaoudi et al., 2007; Kuipers, Trentani et al., 2016) had no effect on CA1 LTP. These findings suggest that Arc's role in memory consolidation is likely mediated through mechanisms that do not involve the maintenance of synaptic potentiation.

\section{Materials and Methods}

Animals. Experiments were performed in three different Arc KO models. Two full Arc knock-out animal lines were used: the $\operatorname{Arc}^{\text {tmiStl }}$ (Wang et al., 2006) line, where GFP was knocked into the endogenous Arc locus (Arc ${ }^{\mathrm{GPP} / \mathrm{GFP}}$ ), and the Kuhl $\mathrm{Arc}^{-1-}$ line (Plath et al., 2006). An Arc conditional KO line $\left(\operatorname{Arc}^{\mathrm{f} / \mathrm{fl}}\right)$, which was previously generated (provided by Richard Palmiter, University of Washington), was also used. In this line, loxP sites were inserted to enable the removal of the entire Arc gene on introduction of cre-recombinase (Chen et al., 2018). All lines are on the C57BL6 background, and WT littermates were used as controls. C57BL6 WT mice were used for the Arc antisense ODN experiments. All procedures were approved by the Institutional Animal Care and Use Committees of the University of Utah, The Johns Hopkins University, and the Massachusetts Institute of Technology, in conjunction with National Institutes of Health guidelines.

In vitro electrophysiology. Slices were prepared from WT and KO mice at age 6-8 weeks (Arc cKO and Arc ${ }^{\text {GFP/GFP }}$ and WT alone for ODN) or 11-14 weeks $\left(\mathrm{Arc}^{-1-}\right)$ of either sex. Mice were anesthetized with the inhalation anesthetic isoflurane before decapitation. Four hundred $\mu \mathrm{m}$ transverse slices were prepared using a Leica VT1200S vibratome $\left(\mathrm{Arc}^{-1-}\right)$ or a Leica VT1000S vibratome (Arc cKO, $\mathrm{Arc}^{\mathrm{GFP} / \mathrm{GFP}}$, and ODN experiments) in ice-cold oxygenated $\left(95 \% \mathrm{O}_{2} / 5 \% \mathrm{CO}_{2}\right)$ dissection buffer containing the following (in $\mathrm{mm}$ ): $2.6 \mathrm{KCl}, 1.25 \mathrm{NaH}_{2} \mathrm{PO}_{4}$, $26 \mathrm{NaHCO}_{3}, 211$ sucrose, 10 glucose, $0.75 \mathrm{CaCl}_{2}, 7 \mathrm{MgCl}_{2}$. Slices were recovered in a static submersion chamber for at least $2 \mathrm{~h}$ in $30^{\circ} \mathrm{C}$ aCSF containing the following (in $\mathrm{mM}$ ): $125 \mathrm{NaCl}, 5 \mathrm{KCl}, 25 \mathrm{NaHCO}_{3}, 1.25$ $\mathrm{NaH}_{2} \mathrm{PO}_{4} \cdot \mathrm{H}_{2} \mathrm{O}, 11$ glucose, $2 \mathrm{CaCl}_{2}, 1 \mathrm{MgCl}_{2}$. Field excitatory postsynaptic potentials (fEPSPs) were evoked at $0.033 \mathrm{~Hz}$ with a $125 \mathrm{~mm}$ platinum/iridium concentric bipolar electrode (FHC; $\mathrm{Arc}^{-1-}$ ) or $75 \mathrm{~mm}$ Tungsten bipolar electrode (World Precision Instruments; Arc cKO, $\mathrm{Arc}^{\mathrm{GFP} / \mathrm{GFP}}$, and ODN experiments) placed in the middle of stratum radiatum of CA1. A 1-4 M $\Omega$ glass recording electrode filled with aCSF was positioned $200-400 \mu \mathrm{m}$ away (orthodromic) from the stimulating electrode. Input-output $(\mathrm{I} / \mathrm{O})$ curves were obtained for each slice, and stimulus intensity for all subsequent recordings was set to elicit a fEPSP slope that was $30-40 \%$ of the maximum response. Recording aCSF was identical to recovery conditions and slices were incubated at a flow rate of $3 \mathrm{ml} / \mathrm{min}$ at $32^{\circ} \mathrm{C}$. Stimulation protocols were as follows: protein-synthesis-independent early-phase LTP (E-LTP): 20 pulses at $100 \mathrm{~Hz}$; moderate frequency stimulation: 900 pulses at $10 \mathrm{~Hz}$; high-frequency stimulation LTP: 2 trains of 100 pulses at 100; and theta burst protein-synthesis-dependent late-phase LTP (L-LTP): four trains at $10 \mathrm{~s}$ intertrain intervals. Each train consisted of 10 bursts at $5 \mathrm{~Hz}$, with each burst containing four stimuli at $100 \mathrm{~Hz}$.

Antisense oligodeoxynucleotides. Arc ODNs (5'GTC CAG CTC CAT CTG CTC GC $3^{\prime}$ ) and scrambled Arc ODNs (5'CCT GCT GAC CTC CGT ATG CC $3^{\prime}$ ) previously described (Messaoudi et al., 2007; Kuipers et al., 2016) were synthesized (Integrated DNA Technologies) and used at a final concentration of $1 \mu \mathrm{m}$ in aCSF. After a $10 \mathrm{~min}$ baseline recording, slices were bathed in aCSF containing ODNs for the remainder of the experiment.

In vivo electrophysiology. Male mice were anesthetized under isoflurane (3\% for induction and $1.5 \%$ for maintenance) and head-fixed in a stereotaxic frame. Rectal temperature was maintained at $37^{\circ} \mathrm{C}$ using a heat blanket. A dental drill was used to make craniotomies in the skull, and electrodes were placed according to established stereotaxic coordinates on the left-hand side of the brain. For LTP experiments in the dentate gyrus, a concentric bipolar stimulating electrode (Rhodes Medical Instruments) was positioned in the medial perforant path (MPP), $3 \mathrm{~mm}$ left of $\lambda$ and at a depth of $\sim 1.5 \mathrm{~mm}$ from brain surface. A glass micropipette was lowered into the hilus of the left dentate gyrus, $2 \mathrm{~mm}$ posterior to bregma, $1.6 \mathrm{~mm}$ left of the midline and at a depth of $\sim 1.5 \mathrm{~mm}$, to record positive-going evoked field responses next to the granule cell bodies. Correct placement of the stimulating electrode in the MPP was confirmed by the characteristic short latency onset of the evoked field response $(2-2.5 \mathrm{~ms})$ and the early onset of the population spike $(\sim 4$ $\mathrm{ms})$. For all experiments, input-output relationships were assessed using a range of stimulus intensities from $0-220 \mu \mathrm{A}$, which produced a close to maximal response. Five responses were collected at each intensity and averaged. Test responses for LTP experiments were evoked by monophasic stimuli set at an intensity to evoke a response $\sim 50 \%$ of maximum fEPSP slope and a population spike of $\sim 1 \mathrm{mV}(100-220 \mu \mathrm{A}, 60 \mu \mathrm{s})$. A stable $30 \mathrm{~min}$ baseline was acquired before delivering a theta burst tetanus to induce LTP. The tetanus comprised six series of six trains of six stimuli at $400 \mathrm{~Hz}$ with $200 \mathrm{~ms}$ between trains and $20 \mathrm{~s}$ between series. Pulse width was doubled during the tetanus to $120 \mu$ s. Only the very early component of the EPSP slope was measured for analysis to ensure that there was no contamination by the population spike. The slope of the fEPSP was expressed as a percentage change relative to the averaged baseline response. At the end of each experiment, the anesthetized mouse was killed by cervical dislocation. 
Viral injection. Mice were anesthetized with isoflurane (3\% for induction, $1.5-2 \%$ for surgery) and placed in a stereotaxic frame following the suppression of reflexes. The antibiotic Baytril ( $8 \mathrm{mg} / \mathrm{kg}$; VetOne), the analgesic Carprofen $(5 \mathrm{mg} / \mathrm{kg}$; Zoetis) and the anti-inflammatory dexamethasone (13 mg/kg; VetOne) were administered before placing the mouse in the stereotax to control pain/swelling. Lidocaine $(100 \mathrm{mg} /$ $\mathrm{kg}$; VetOne) was then injected subcutaneously beneath the scalp before incision. The skin was incised to expose the skull and a small burr hole was made with a pneumatic dental drill above the CA1 region of the hippocampus $(350 \mu \mathrm{m}$ lateral and $50 \mu \mathrm{m}$ anterior to LAMBDA). A pulled glass pipette, backfilled with mineral oil and filled with virus, was lowered $(250 \mu \mathrm{m}$ below surface) and allowed to rest for $5 \mathrm{~min}$. Bilateral injections of either AAV5/CaMKII-GFP $(3.18 \times 108$ particles, $1 \mu \mathrm{l}$ volume; Ed Boyden, University of North Carolina Vector Core) or AAV5/ CaMKII-GFP-cre $(2.1 \times 108$ particles, $1 \mu$ l volume; University of North Carolina Vector Core) were delivered using a Nanoject II AutoNanoliter Injector (Drummond Scientific). Following a further $5 \mathrm{~min}$ resting postinjection, the pipette was slowly removed. The scalp was then sutured closed and the animal was placed in a warm cage for recovery. Animals were maintained at $\sim 37^{\circ} \mathrm{C}$ throughout the procedure and recovery, and general condition and reflex signs were monitored closely. Mice were monitored postoperatively for signs of infection or discomfort. Animals recovered for 2 weeks to allow for viral expression before slice preparation. To quantify the effectiveness of cre to knock-out Arc expression in these animals, slices used for electrophysiology were subsequently prepared for Western blotting to assess Arc protein levels. Slices were only used for experiments if GFP could be detected along the entire CA1 region of each slice before electrophysiology. GFP was visualized in slices using an LED light source at $470 \mathrm{~nm}$ (pE-100; CoolLED) on a SliceScope Pro-Mounted FireWire (B FWCAM X M) camera linked to the SCIlight 2.2 software (Scientifica).

Immunohistochemistry. A representative image of GFP injection was made from an animal injected with AAV5:CaMKII-GFP, as described above. After 2 weeks recovery, the animal was perfused with $4 \%$ paraformaldehyde, followed by $24 \mathrm{~h}$ fixation in further $4 \%$ paraformaldehyde. The brain was cryoprotected in 30\% sucrose before being sectioned $(30 \mu \mathrm{m})$ on a cryostat. Sections were stained for DAPI (catalog \#R37606, Thermo Fisher Scientific; $5 \mathrm{~min}$ at room temperature) before mounting coverslips on slides in Fluoromount (catalog \#F4680, Millipore Sigma) and dried. Images were captured on the confocal microscope (Ti2, Nikon).

Western blotting. After the CA1 region of the hippocampus was dissected from slices postelectrophysiology, tissue was mixed in $4 \times$ Laemlli Buffer (40\% glycerol, $250 \mathrm{~mm}$ Tris, $4 \%$ SDS, $50 \mathrm{~mm} \mathrm{STT,} \mathrm{pH} \mathrm{6.8)} \mathrm{and}$ boiled at $95^{\circ} \mathrm{C}$ for $10 \mathrm{~min}$. SDS-PAGE gel electrophoresis was used to separate protein samples. Separated samples were transferred to a nitrocellulose membrane (GE Healthcare). Following transfer, membranes were briefly stained with $0.1 \%$ Ponceau stain, destained with $1 \%$ acetic acid to remove background, and then imaged to detect total protein. Membranes were blocked in $5 \%$ milk $+1 \times$ tris-buffered saline (TBS; $10 \times$ : $152.3 \mathrm{~mm}$ Tris-HCl, $46.2 \mathrm{~mm}$ Tris base, $1.5 \mathrm{~m} \mathrm{NaCl}, \mathrm{pH}$ 7.6, for $30 \mathrm{~min}$ at room temperature. Membranes were then incubated with primary antibody against Arc $(1: 1000$, custom rabbit polyclonal, Protein Tech) in $1 \times$ TBS, overnight at $4^{\circ} \mathrm{C}$. Membranes were washed in $1 \times$ TBS $(3 \times 10 \mathrm{~min})$ before being incubated in a secondary antibody (1:10,000 HRP-conjugated goat antirabbit, Jackson ImmunoResearch), in blocking solution described above, for $1 \mathrm{~h}$ at room temperature. Membranes were then washed again in $1 \times$ TBS $(3 \times 10 \mathrm{~min})$. A chemiluminescent kit was used to detect protein bands (Bio-Rad). Membranes were imaged on an Azure c300 gel dock (Azure Biosystems). Blots were analyzed and quantified using the Gel Analysis plug-in in ImageJ.

Statistics. For all LTP experiments, the magnitude of LTP over the first $5 \mathrm{~min}$ poststimulation and the last $5 \mathrm{~min}$ of recording was averaged for each slice. Unpaired two-tailed $t$ tests were performed on these averages from the Arc KO and WT littermates for each experiment. For I/O curves, linear regression was fitted for each curve $( \pm 95 \%$ confidence interval) and an extra-sum-of-squares $F$ test was used to compare slope of the best fit line between KO and WT groups. For paired pulse, a twoway ANOVA was performed to determine whether there was a genotype
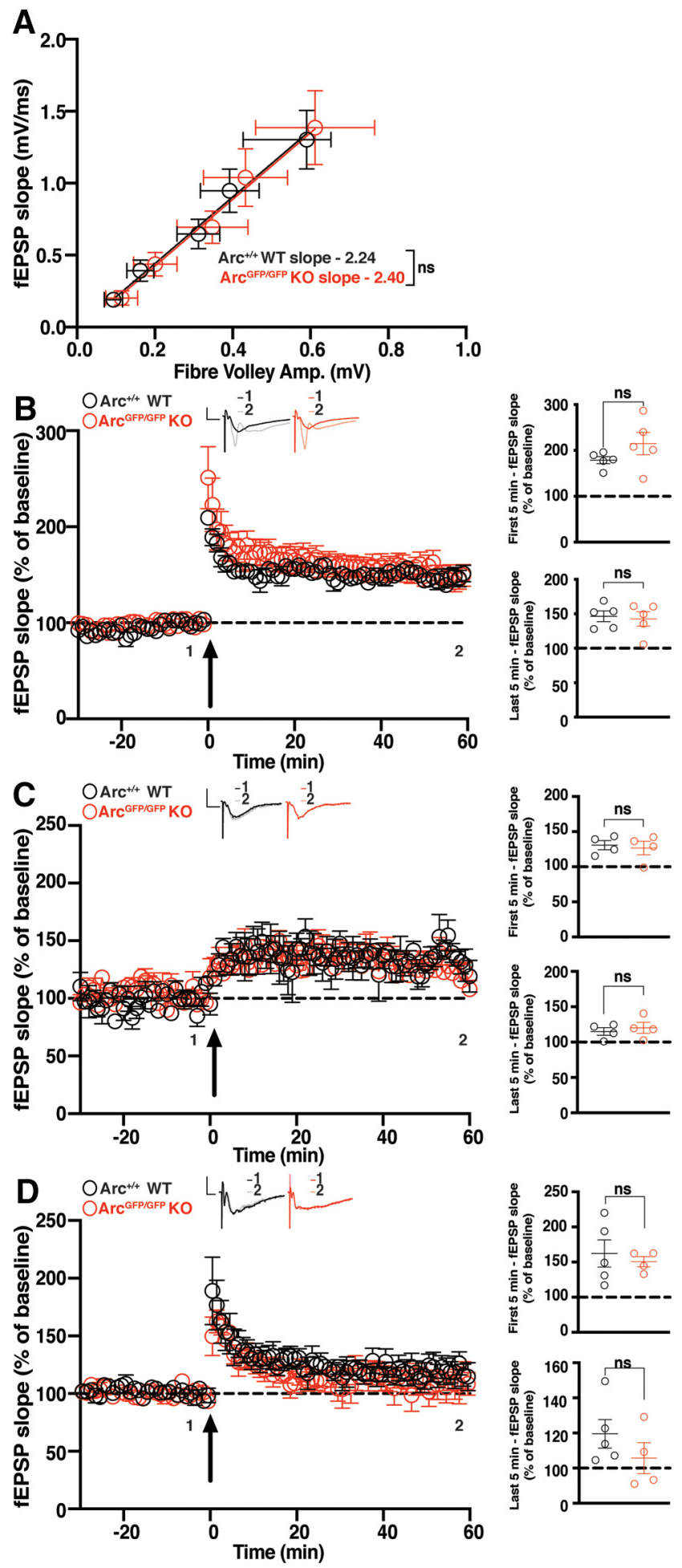

Figure 1. HFS CA1 LTP is normal in Arc K0 animals. $\boldsymbol{A}$, There was no significant difference in basal synaptic transmission between Arc ${ }^{\text {GFP/GFP }}$ KO (red circles) and WT (black circles) littermates. $\boldsymbol{B}$, There was no significant difference in the average magnitude of LTP over the first 5 min poststimulation, nor over the last 5 min of recording, between $\operatorname{Arc}^{\text {GFP/GFP }}, \mathrm{KO}$, and WT littermates when LTP was induced using a $2 \times$ HFS (100 pulses at $100 \mathrm{~Hz})$ protocol. C, There was no significant difference in the magnitude of LTP over the first 5 min poststimulation, nor over the last 5 min of recording (b), between the Arc ${ }^{\text {GFP/GFP }}$, KO, and WT littermates when LTP was induced using a moderate frequency protocol ( 900 pulses at $10 \mathrm{~Hz}$ ). $\boldsymbol{D}$, There was no significant difference in the magnitude of E-LTP over the first 5 min poststimulation, nor over the last 5 min of recording, between the $\operatorname{Arc}^{\text {GFP/GFP }}, K 0$, and WT littermates when E-LTP was induced using weak, high-frequency stimulation protocol ( 20 pulses at $100 \mathrm{~Hz}$ ). Data are represented as mean \pm SEM. Scale bars: $0.5 \mathrm{mV}$ (horizontal) and $5 \mathrm{~ms}$ (vertical). 

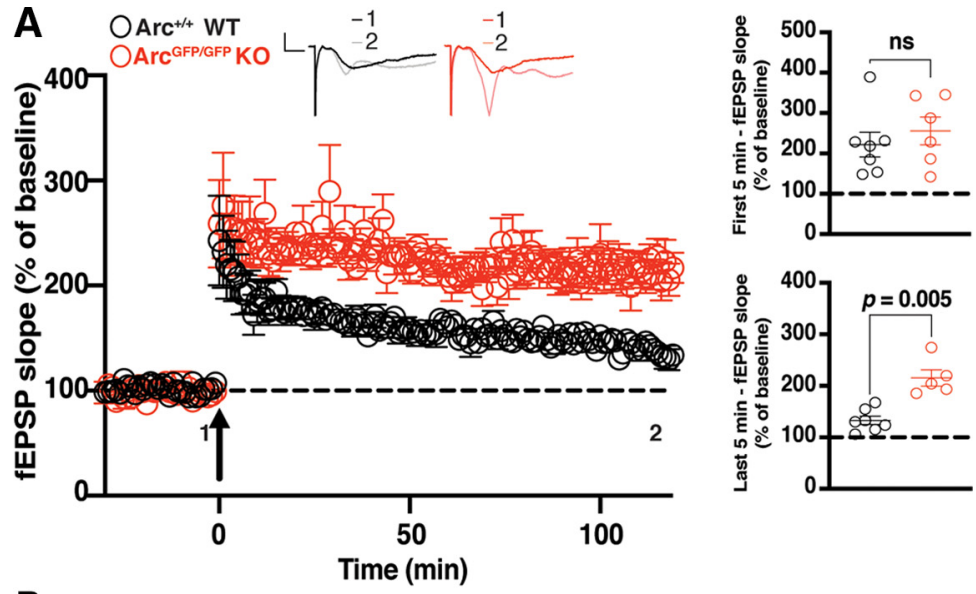

B
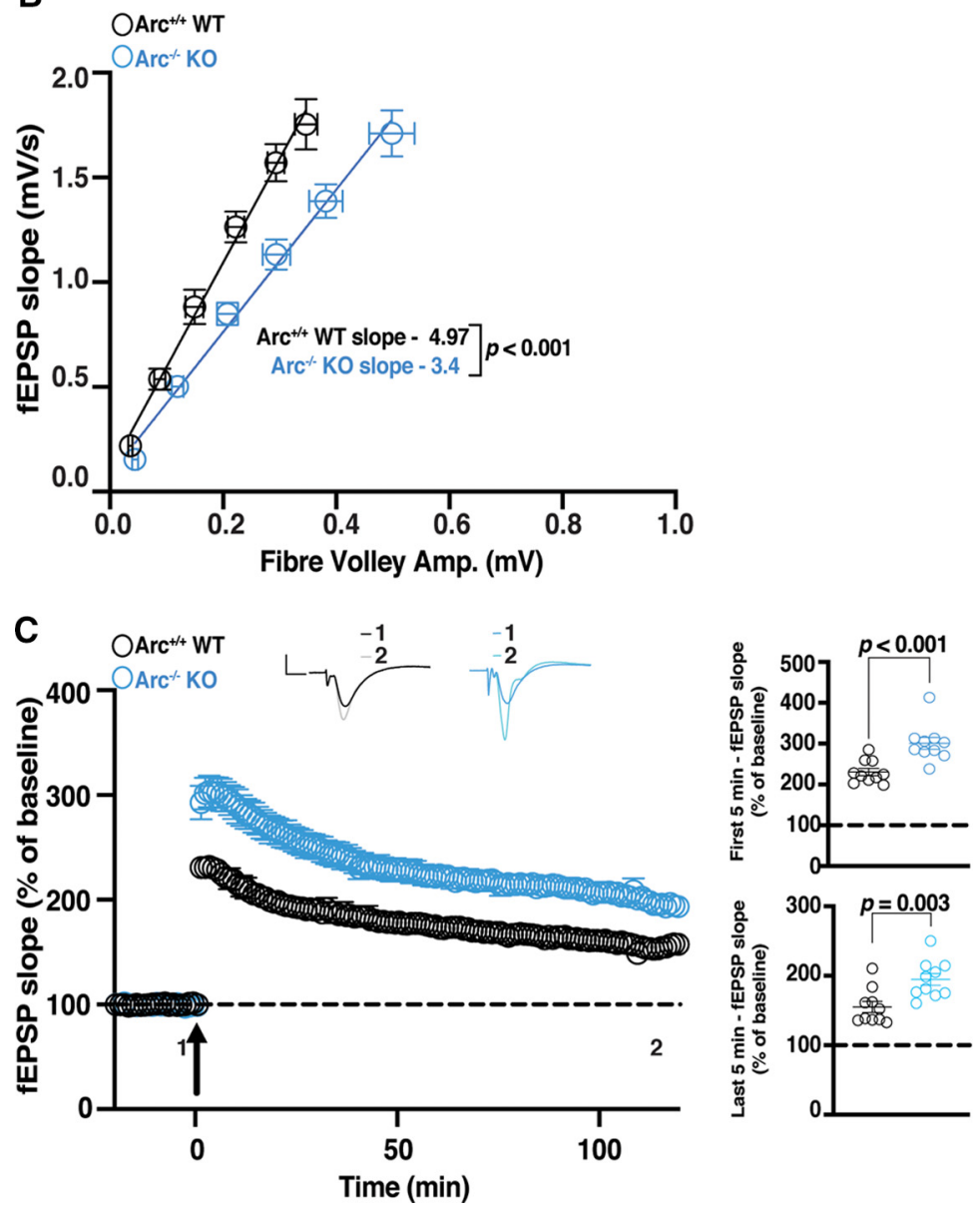

Figure 2. TBS CA1 LTP is enhanced in germline Arc K0 animals. $\boldsymbol{A}$, There was no significant difference in the magnitude of LTP over the first 5 min poststimulation between the Arc ${ }^{\text {GFP/GFP }}$, KO (red circles), and WT (black circles) littermates, but the magnitude of LTP was significantly greater in Arc ${ }^{\text {GFP/GFP }} \mathrm{KO}$ mice compared with WT littermates over the last 5 min of recording, when LTP was induced using a theta-burst stimulation protocol (4 trains at $10 \mathrm{~s}$ intertrain intervals; each train consisted of 10 bursts at $5 \mathrm{~Hz}$, with each burst containing 4 stimuli at $100 \mathrm{~Hz}$ ). B, Basal synaptic transmission was significantly weaker in $\mathrm{Arc}^{-1-} \mathrm{KO}$ (blue circles) mice compared with WT (black circles) littermates. C, The magnitude of LTP over the first 5 min postsimulation, and over the last 5 min of recording, was significantly greater in the $\mathrm{Arc}^{-1-} \mathrm{KO}$ (blue circles) mice compared with WT (black circles) littermates when LTP was induced using a theta-burst stimulation protocol (4 trains at $10 \mathrm{~s}$ inter-train intervals; each train consisted of 10 bursts at $5 \mathrm{~Hz}$, with each burst containing 4 stimuli at $100 \mathrm{~Hz}$ ). Data are represented as mean \pm SEM. Scale bars: $0.5 \mathrm{mV}$ (horizontal) and $5 \mathrm{~ms}$ (vertical).

by ISI effect, with Sidak's post hoc multiple-comparison analysis of the difference between genotype at each Inter-stimulus interval (ISI). For Western blot analysis, Arc signal was normalised to total protein, and then the fold change (FC) for all samples were calculated from the average of the GFP-only group (sample/average of control group). Unpaired two-tailed $t$ tests were then performed between the two groups (GraphPad Prism; GraphPad software was used for all statistics.).

\section{Results}

Arc is not required for LTP induced by high-frequency stimulation in CA1

Broadly, LTP can be divided into E-LTP or L-LTP (Nguyen et al., 1994). These types of LTP can also be induced by a variety of stimulation protocols. To test the role of Arc in different types of hippocampal LTP, we used multiple high-frequency stimulation (HFS) paradigms to induce plasticity at CA3 to CA1 synapses in hippocampal slices. As Arc expression increases within minutes of HFS, we hypothesized that Arc would be required for the maintenance of LTP induced by HFS. To test this, we used a standard HFS protocol that typically induces LTP that persists for at least $1 \mathrm{~h}$. We used Arc ${ }^{\text {GFP/GFP }}$ mice, 6-8 weeks old, which show no differences in basal transmission (WT slope $=2.237 \pm 0.64, n=20$; Arc $^{\text {GFP/GFP }}$ KO slope $=2.397 \pm 0.80, n=21$; linear regression, extra-sum-of-squares $F$ test between curves: $F_{(1,190)}=0.096, p=0.756$; Fig. $1 A$ ). There was no significant difference in the magnitude of LTP induced by a $2 \times$ HFS $(100 \mathrm{~Hz})$ protocol between Arc ${ }^{\text {GFP/GFP }}$ $\mathrm{KO}$ and WT littermates (WT $178.84 \% \pm$ $7.72, n=5 ; \mathrm{KO} 214.83 \% \pm 24.44, n=5$; $t$ test: $p=0.20$ ), nor was there a difference in the magnitude of LTP $1 \mathrm{~h}$ poststimulation (WT $146.48 \% \pm 7.63, n=5 ; \quad \mathrm{Arc}^{\mathrm{GFP} / \mathrm{GFP}} \mathrm{KO}$ $141.29 \% \pm 10.12, n=5 ; t$ test: $p=0.69$; Fig. $1 B)$.

Surprised by this result, we hypothesised that perhaps the loss of Arc would lower the threshold for LTP induction (Shepherd and Bear, 2011) rather than mediate LTP maintenance or expression. We tested a moderate frequency stimulation protocol of 900 pulses at $10 \mathrm{~Hz}$ that typically induces little to no change in synaptic strength (Dudek and Bear, 1992). There was no significant difference in the magnitude of LTP induced between $\mathrm{Arc}^{\mathrm{GFP} / \mathrm{GFP}} \mathrm{KO}$ and WT littermates (WT 124.7\% \pm 6.67, $n=4$; $\operatorname{Arc}^{\text {GFP/GFP }}$ KO $125.3 \% \pm 9.65, n=4 ; t$ test: $p=0.96$ ), nor a difference in the magnitude of LTP $1 \mathrm{~h}$ poststimulation (WT 115\% \pm $5.35, n=4 ; \mathrm{Arc}^{\mathrm{GFP} / \mathrm{GFP}} \mathrm{KO} 120.2 \% \pm 7.74$, $n=4 ; p=0.60$; Fig. 1C). To further test the threshold hypothesis, we used a low repetition, high-frequency stimulation protocol that typically only induces E-LTP (20 pulses at $100 \mathrm{~Hz}$; Frey and Morris, 1997). There was no significant difference in the magnitude of LTP induced between Arc ${ }^{\mathrm{GFP} / \mathrm{GFP}} \mathrm{KO}$ and WT littermates (WT 162.25\% $\pm 19.4, n=5$, Arc ${ }^{\text {GFP/GFP }}$ KO $150.65 \% \pm$ 7.21, $n=4$; $t$ test: $p=0.63$ ), nor was there a difference in the 
magnitude of LTP $1 \mathrm{~h}$ poststimulation (WT $119.54 \% \pm 8.12, n=5, \mathrm{Arc}^{\mathrm{GFP} / \mathrm{GFP}}$ KO $105.6 \% \pm 8.81, \mathrm{n}=4$; $t$ test: $p=0.29$; Fig. 1D). These results show that Arc is not required for HFS-induced LTP, nor does loss of Arc change the threshold of LTP induction in the CA1 region of the hippocampus.

\section{CA1 LTP induced by theta burst}

stimulation is increased in Arc KO mice To further probe whether Arc mediates specific types of LTP, we tested another robust and commonly used L-LTP induction protocol, theta burst stimulation (TBS; Larson et al., 1986; Thomas et al., 1998; Volk et al., 2013). In addition, we recorded for $2 \mathrm{~h}$ after LTP induction to further determine whether maintenance of L-LTP was affected. The initial magnitude of LTP was not significantly different between Arc GFP/GFP KO and WT littermates (WT $222.0 \% \pm 30.7, n=6$; KO $255.6 \% \pm 34.3$, $n=7$; $t$ test: $p=0.48$; Fig. $2 A$ ). However, $1 \mathrm{~h}$ (WT 221.96\% $\pm 30.72, n=7$; KO $255.6 \%$ $\pm 34.3, n=6$; $t$ test $p=0.004)$ and 2 h poststimulation, the magnitude of LTP was significantly greater in $\mathrm{Arc}^{\mathrm{GFP} / \mathrm{GFP}} \mathrm{KO}$ mice compared with WT littermates (WT $132.9 \% \pm 8.17, n=6$; KO $215.4 \% \pm 14.46$, $n=7$; $t$ test: $p=0.0005$; Fig. $2 A$ ). Because this Arc KO line expresses GFP from the Arc locus, we also investigated whether TBS L-LTP was altered in a different germline Arc KO line, $\mathrm{Arc}^{-1-}$ mice (Plath et al., 2006). Interestingly, we found a small but significant difference in basal transmission in this line $(\mathrm{WT}$ slope $=4.97 \pm 0.60, n=16$; $\mathrm{Arc}^{-1-} \mathrm{KO}$ slope $=3.4 \pm 0.36, n=15$; linear regression, extra-sum-of-squares $F$ test between curves: $F_{(1,175)}=21.37, p<0.0001$; Fig. 2B). The initial magnitude of L-LTP induced was significantly greater in $\mathrm{Arc}^{-/-}$ mice compared with WT littermates (WT $230.46 \% \pm 8.88, n=10 ; \mathrm{KO} 300.63 \% \pm$ 14.45, $n=10$; $t$ test: $p=0.0006$; Fig. $2 C$ ). Similarly, the magnitude of LTP $1 \mathrm{~h}$ (WT $177.7 \% \pm 9.91, n=9$; KO $226.55 \% \pm$ 10.17, $n=10$; $t$ test $p=0.003$ ) and $2 \mathrm{~h}$ (WT $155.11 \% \pm 8.27, n=10 ; \mathrm{KO} 194.72 \% \pm$ $8.55, n=10$; $t$ test: $p=0.003$ ) postinduction was significantly greater in $\mathrm{Arc}^{-1-}$ mice than WT littermates (Fig. 2C). These results show that Arc is not required for the maintenance of TBS L-LTP and that loss of Arc may lead to an increase in TBS LTP magnitude when Arc is absent throughout development.

CA1 LTP induced by theta burst stimulation is normal in conditional Arc KO mice

The enhanced magnitude of L-LTP after TBS in germline Arc KO lines may be the result of compensatory mechanisms during development. To temporally restrict the loss of Arc, we used a floxed Arc KO line ( $\mathrm{Arc}^{\mathrm{f} / \mathrm{fl}}$; Chen et al., 2018) injected at 4-6 weeks of

B

C
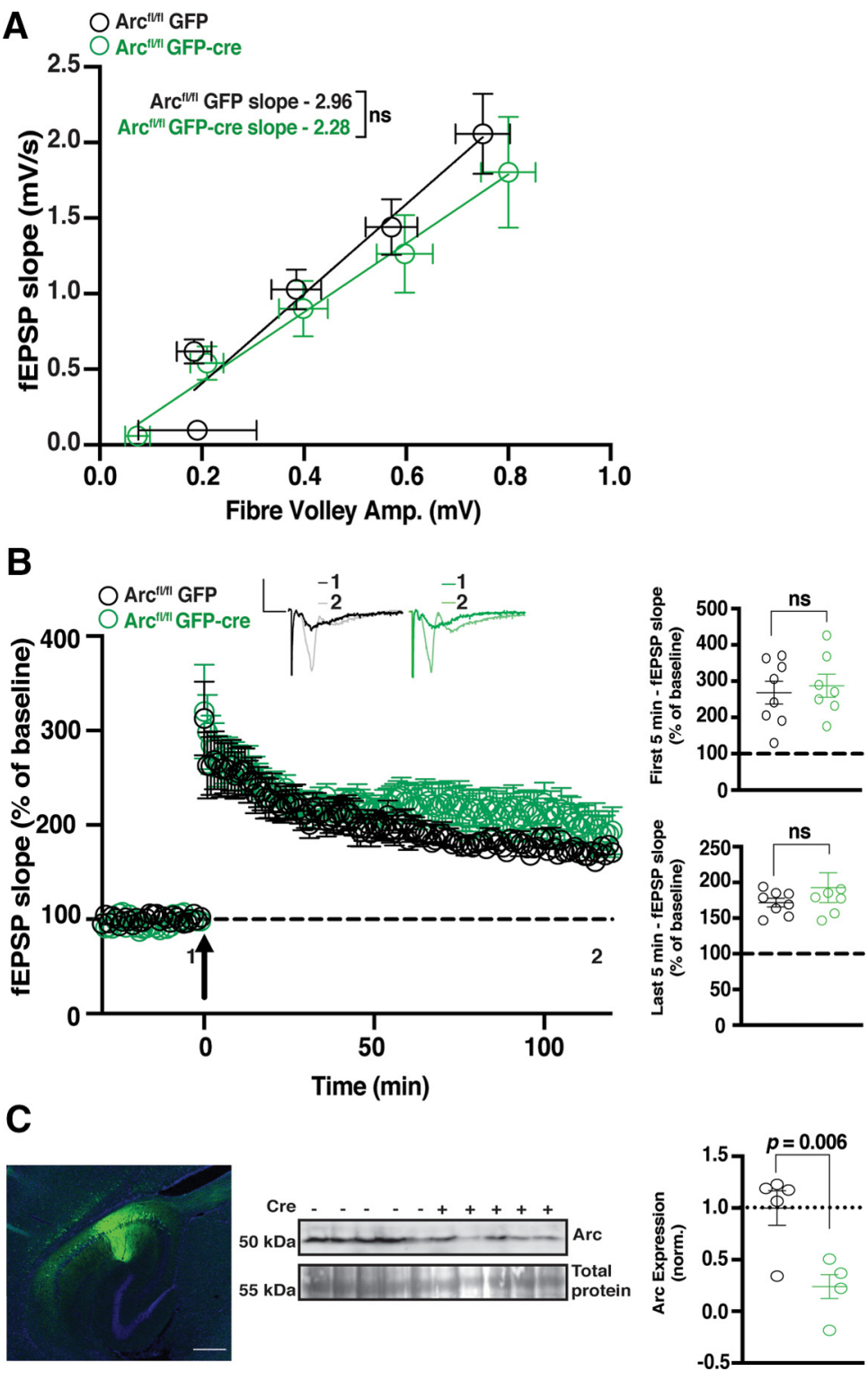

Figure 3. TBS CA1 LTP is normal in Arc fl/fi animals. $\boldsymbol{A}$, There was no significant difference in basal synaptic transmission between Arc $^{\mathrm{fl} / \mathrm{f}}$ animals injected with GFP and GFP-Cre-injected animals. $\boldsymbol{B}$, There was no significant difference in the magnitude of LTP over the first 5 min poststimulation, nor over the last $5 \mathrm{~min}$ of recording, between $\operatorname{Arc}^{\mathrm{fl} / \mathrm{fl}}$ animals injected with GFP-cre and those injected with GFP alone when LTP was induced using a theta-burst stimulation protocol (4 trains at $10 \mathrm{~s}$ intertrain intervals; each train consisted of 10 bursts at $5 \mathrm{~Hz}$, with each burst containing 4 stimuli at $100 \mathrm{~Hz}$ ). Data are represented as mean \pm SEM. Scale bars: $0.5 \mathrm{mV}$ (horizontal) and $5 \mathrm{~ms}$ (vertical). C, Arc protein expression was significantly reduced in Arc/l/f animals injected with GFP-cre (green circles) compared with GFP alone (black circles). Inset, Representative image of GFP expression (green is GFP, blue is DAPI), 2 weeks postinjection of AAV:CaMKII-GFP-cre into the CA1 region of the hippocampus. Scale bar, $500 \mu \mathrm{m}$.

age with AAV5/CaMKII-GFP-cre (GFP-cre) to knock-out Arc in excitatory neurons of CA1, or AAV5/CaMKII-GFP alone (GFP) as a matched injection control. Two weeks after viral expression (6-8 weeks of age), slices were prepared for electrophysiology. Slices were used for recordings if GFP was identified along the length of the CA1 region of the hippocampus (Fig. 3, inset). Basal transmission was similar between $\operatorname{Arc}^{\mathrm{fl} / \mathrm{fl}}$ animals injected with GFP and GFP-Cre injected animals (GFP slope $=2.96 \pm 0.69$, $n=8$; GFP-cre slope $=2.28 \pm 0.75, n=7$; linear regression, extrasum-of-squares $F$ test between curves: $F_{(1,71)}=1.866, p=0.18$; Fig. $3 A)$. We found no difference in the initial magnitude of TBSinduced LTP between $\mathrm{Arc}^{\mathrm{fl} / \mathrm{fl}}$ animals injected with GFP-cre and those injected with GFP alone (GFP 271.1\% $\pm 25.79, n=8$; GFP- 
A
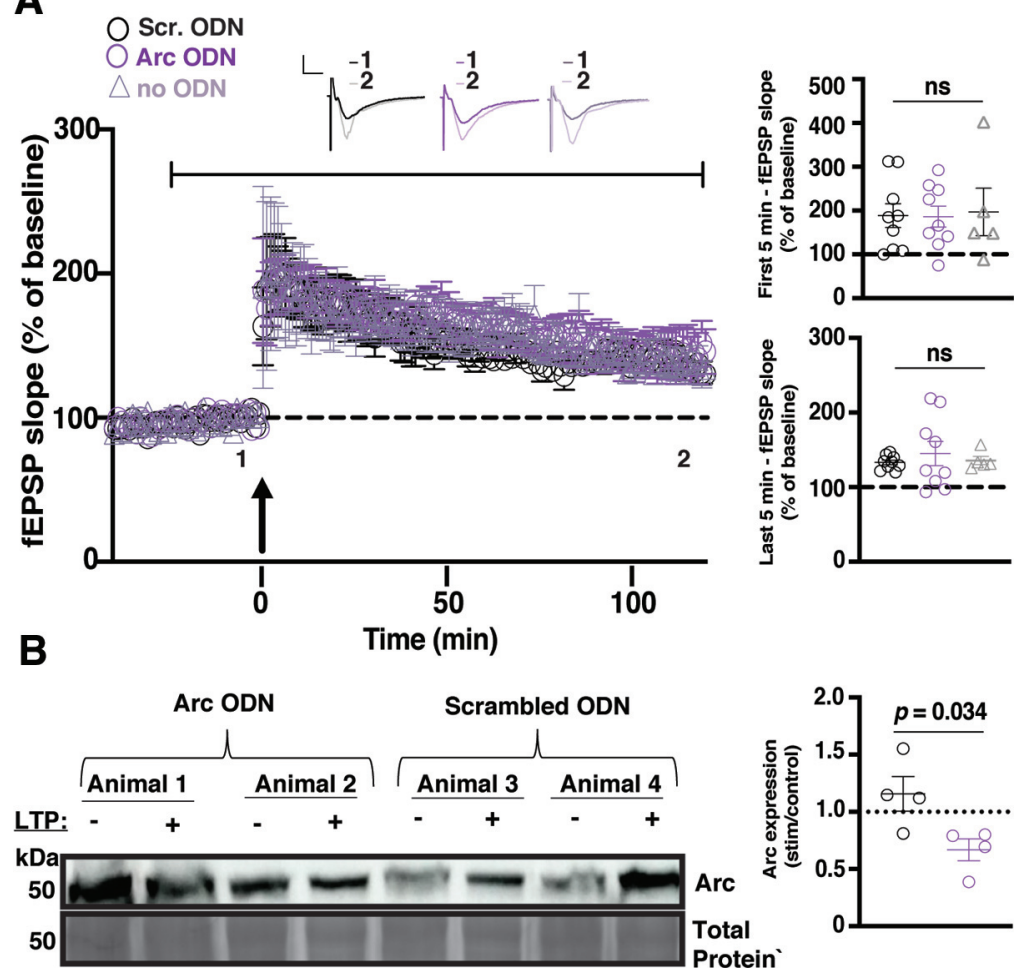

Figure 4. LTP is normal in the presence of Arc antisense ODNs. A, The magnitude of LTP was not significantly different between slices incubated in aCSF containing an ODN against Arc (purple circles), a scrambled ODN (black circles), or normal aCSF (gray triangles) over the first 5 min poststimulation or the last 5 min poststimulation when LTP was induced using a theta-burst stimulation protocol (4 trains at $10 \mathrm{~s}$ intertrain intervals; each train consisted of 10 bursts at $5 \mathrm{~Hz}$, with each burst containing 4 stimuli at $100 \mathrm{~Hz}$ ). Data are represented as mean \pm SEM. Scale bars: $5 \mathrm{mV}$ (horizontal) and $5 \mathrm{~ms}$ (vertical). After a $10 \mathrm{~min}$ baseline recording, normal aCSF was switched to aCSF containing ODN for the duration of the recording, as indicated by the black bar above the graph. $\boldsymbol{B}$, Arc protein expression increased after TBS in the slices that were incubated with the scrambled ODN (black circles) but not in those that were incubated with the Arc ODN (purple circles).

Cre $281.1 \% \pm 37.35, n=7$; $t$ test: $p=0.68$; Fig. $3 B$ ). There was also no significant difference in the magnitude of LTP $2 \mathrm{~h}$ postinduction (GFP 180.8\% $\pm 20.79, n=8$; GFP-Cre 193.4\% $\pm 36.77, n=7$; $t$ test: $p=0.32$; Fig. $3 B)$. These results show that knockdown of Arc postdevelopment has no effect on the induction or maintenance of TBS L-LTP. To determine the magnitude of Arc depletion, we measured Arc protein levels by Western blot analysis from the stimulated CA1 region of a subset of slices, postrecording. Arc was significantly reduced in slices from $\mathrm{Arc}^{\mathrm{fl} / \mathrm{fl}}$ animals injected with GFP-cre compared with GFP alone (GFP $1 \pm 0.17$, $n=5$; GFP-Cre $0.24 \pm 0.11, n=5$; $t$ test: $p=0.006$; Fig. $3 C$ ).

CA1 LTP induced by theta burst stimulation is normal in slices incubated with Arc antisense ODNs

It is possible that compensatory mechanisms may still be initiated with 1-2 weeks of Arc knockdown. To determine if acute Arc knockdown could interfere with CA1 LTP, we used Arc antisense ODNs previously used in LTP studies (Messaoudi et al., 2007). After a $10 \mathrm{~min}$ stable baseline recording in normal aCSF, a switch was made to aCSF containing Arc ODNs or scrambled ODNs. Following a further $30 \mathrm{~min}$ baseline, TBS LTP was induced, and recordings were followed for $2 \mathrm{~h}$. In some experiments, slices were collected for Western blot analysis. There was no change in synaptic responses after the aCSF switch during baseline recordings (Fig. $4 A$ ). We found no difference in the initial magnitude of LTP between slices treated with the Arc ODN, the scrambled ODN, and slices incubated in normal aCSF
(Scrambled ODN 188.5\% \pm 27.22, $n=9$; Arc ODN $186.2 \% \pm 24.11, n=9$; aCSF $196.9 \% \pm$ 54.14, $n=5$; one-way ANOVA: $p=0.98$; Fig. $4 A$ ). There was also no significant difference in the magnitude of LTP $2 \mathrm{~h}$ postinduction (Scrambled ODN 133.03\% $\pm 1.04, n=9$; Arc ODN $145.1 \% \pm 16.10, n=9 ;$ no ODN $135.55 \% \pm 5.46, n=5$; one-way ANOVA: $p=0.71$; Fig. $4 A$ ). The lack of functional effects of Arc ODNs may be because of an incomplete effect on blocking Arc synthesis during LTP induction. To test whether Arc ODNs affected Arc protein expression after LTP, we compared Arc expression in unstimulated slices with slices from the same animal where LTP was induced. We found that Arc expression was increased after LTP in slices treated with scrambled ODNs ( $1.16 \pm 0.15, n=4$; Fig. $4 B)$. In contrast, Arc expression was decreased after LTP in slices treated with Arc ODNs and was significantly different from slices incubated with scrambled ODNs $(0.69 \pm 0.10, n=4 t$ test, $p=0.034$; Fig. $4 B$ ), showing that Arc ODNs significantly impaired Arc protein induction after LTP. These results suggest that acutely blocking de novo Arc synthesis during and after LTP induction has no effect on CA1 TBS LTP.

\section{Arc is not required for the maintenance of LTP induced by theta burst stimulation in the dentate gyrus in vivo}

Finally, we assessed whether Arc is required for LTP in vivo in the DG at medial perforant path-granule cell synapses. There was no significant difference in basal transmission in the DG between Arc ${ }^{\mathrm{GFP} / \mathrm{GFP}} \mathrm{KO}$ and WT littermates (WT slope $=0.011 \pm 0.001, n=6$; $\operatorname{Arc}^{\mathrm{tm} 1 \mathrm{Stl}} \mathrm{KO}$ slope ;= $0.013 \pm 0.002, n=6$; linear regression, extra-sum-of-squares $F$ test between curves: $F_{(2,272)}=2.024, p=0.13$; Fig. $\left.5 A\right)$. The initial magnitude of LTP induced by TBS was significantly enhanced in Arc ${ }^{\text {GFP/GFP }} \mathrm{KO}$ animals compared with WT littermate controls (WT 133.13\% \pm 6.87, $n=6$; KO 158.88\% $\pm 4.39, n=6$; $t$ test: $p=0.01$; Fig. $5 B$ ). However, there was no difference in the magnitude of LTP $3 \mathrm{~h}$ poststimulation (WT 134.25\% $\pm 13.03, n=6$; KO $146.45 \% \pm 12.51, n=6 ; p=0.51$; Fig. $5 B$ ). These data further suggest that Arc is not required for the expression or maintenance of L-LTP.

\section{Discussion}

The mechanisms of LTP induction and expression are well defined, but less is known about maintenance. Arc is one of the most robustly expressed genes after LTP induction, with the prevailing view that Arc protein is important for some aspect of LTP (Link et al., 1995; Lyford et al., 1995; Steward et al., 1998; Ying et al., 2002; Moga et al., 2004). Indeed, Arc protein is increased after LTP induction (Lyford et al., 1995; Steward et al., 1998; Ying et al., 2002; Moga et al., 2004) and Arc antisense ODNs have been shown to affect LTP maintenance (Guzowski et al., 2000; Messaoudi et al., 2007). However, relatively few studies have comprehensively tested the role of Arc in hippocampal LTP. Here, we show that LTP is unaffected in the hippocampus 

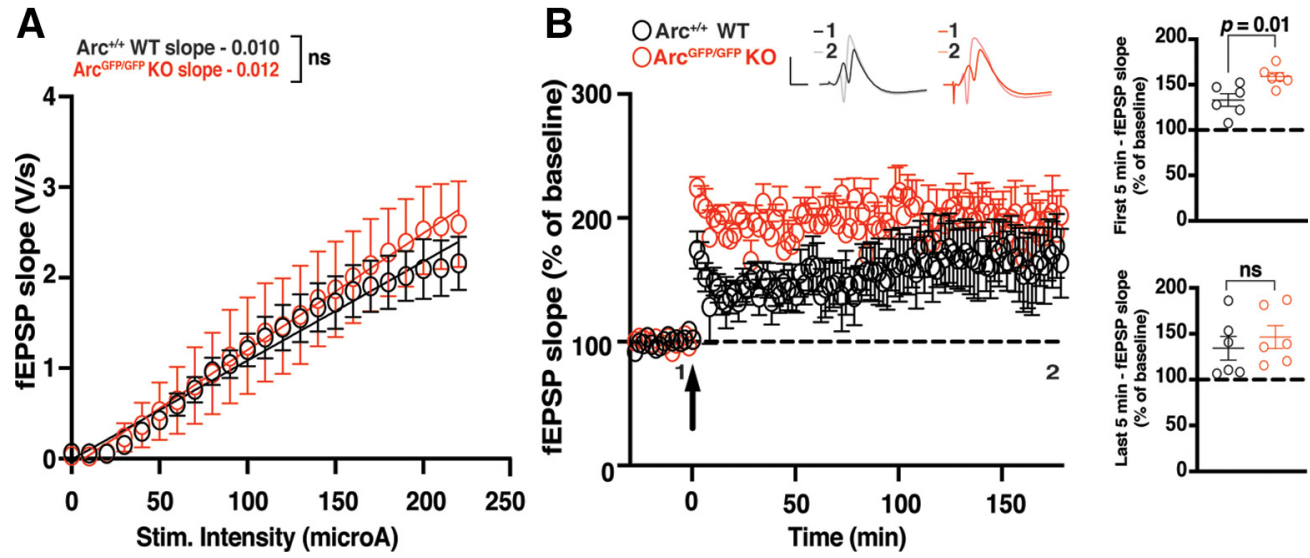

Figure 5. The maintenance of DG LTP in vivo is normal in Arc KO animals. $\boldsymbol{A}$, There was no significant difference in basal synaptic transmission between the Arc ${ }^{\text {GFP/GFP }}$ KO (red circles) and WT (black circles) littermates in the dentate gyrus in vivo. B. The magnitude of LTP over the first 5 min poststimulation was significantly enhanced in Arc ${ }^{\text {GPF/GFP }}$ KO animals compared with WT littermates, but was not significantly different over the last $5 \mathrm{~min}$ of recording when LTP was induced using a theta-burst stimulation protocol $(4$ trains at $10 \mathrm{~s}$ intertrain intervals; each train consisted of 10 bursts at $5 \mathrm{~Hz}$, with each burst containing 4 stimuli at $100 \mathrm{~Hz}$ ). Data are represented as mean \pm SEM. Scale bars: $5 \mathrm{mV}$ (horizontal) and $5 \mathrm{~ms}$ (vertical).

using multiple approaches to interfere with Arc expression and using an array of LTP induction paradigms in slices and in vivo. These data indicate that Arc is not essential for the expression or maintenance of LTP.

\section{Arc is not required for the maintenance of CA1 NMDA receptor-dependent LTP in hippocampal slices}

Standard NMDAR-dependent LTP in the CA1 has not previously been investigated thoroughly in Arc $\mathrm{KO}$ mice. A previous study, using $\mathrm{Arc}^{-1-}$ mice, found that LTP was disrupted in CA1 using a patch-clamp induction protocol (depolarization of the postsynaptic cell paired with 200 presynaptic pulses at $1.5 \mathrm{~Hz}$; Plath et al., 2006). However, we found no significant difference in the maintenance of LTP induced using a standard extracellular field recording HFS protocol $(2 \times 100$ pulses at $100 \mathrm{~Hz}$; Reymann et al., 1985) in Arc ${ }^{\text {GFP/GFP }}$ mice. An NMDAR-independent LTP that requires type 1 mGluRs receptors has also been shown to be impaired in Arc KO animals (Wang et al., 2016). The induction protocol used for this form of LTP relies on blocking of NMDAR during a $200 \mathrm{~Hz}$ stimulation protocol. TBS can also induce robust, persistent LTP and is arguably more physiologically relevant than HFS (Larson et al., 1986; Thomas et al., 1998). Surprisingly, we found that LTP was enhanced in Arc ${ }^{\text {GFP/GFP }}$ KO animals, compared with WT littermates. Recent studies have found behavioral differences between the $\mathrm{Arc}^{-1-}$ and the Arc ${ }^{\text {GFP/GFP }}$ Arc KO lines (Managò et al., 2016; Gao et al., 2019). This may be because of a neomycin cassette present in Arc ${ }^{\text {GFP/GFP }}$, which may lead to off-target effects ( Pham et al., 1996; Scacheri et al., 2001; Gao et al., 2019). We found that basal synaptic transmission is decreased in $\mathrm{Arc}^{-1-}$ mice but normal in Arc ${ }^{\text {GFP/GFP }}$ mice. Nevertheless, similar to the Arc ${ }^{\text {GFP/GFP }}$ line, we find that TBS-induced LTP is enhanced in $\mathrm{Arc}^{-1-}$ mice. However, TBS-induced LTP was unaffected in Arc cKO animals, suggesting that this enhanced LTP may be because of altered plasticity during development in Arc germline $\mathrm{KO}$ animals. Increased dendritic spine size and decreased spine density have been observed in the hippocampus of Arc KO animals (Peebles et al., 2010), and Arc has been shown to regulate developmental plasticity in the visual cortex (McCurry et al., 2010; Jenks et al., 2017; Jenks and Shepherd, 2020) and hippocampus (Gao et al., 2018). Alterations in synapse number and structure can alter the magnitude or type of subsequent plasticity (Harris et al., 1992; Spacek and Harris, 1997; Matsuzaki et al., 2004; Arendt et al.,
2013), and, therefore, disrupted plasticity during development in Arc $\mathrm{KO}$ animals may lead to subsequent changes in adult plasticity that are secondary to the direct functional role of Arc. Consistent with there being no direct functional role of Arc in CA1 LTP, we found the acute block of Arc protein synthesis using Arc antisense ODNs during and after LTP had no effect on LTP magnitude.

Becase LTP expression or maintenance was not impaired in Arc KO mice, we wondered whether the threshold to induce LTP is altered. Metaplasticity, or the plasticity of plasticity, describes the phenomenon where alterations to the basal state of neurons changes the type of plasticity induced by a given specific stimulation paradigm (Abraham and Bear, 1996). For example, the synaptic modification rules based on stimulation frequency, as determined by the Bienstock-Cooper-Munro model, can be altered by differences in NMDAR composition at stimulated synapses (Bienenstock et al., 1982; Dudek and Bear, 1992; Jedlicka, 2002; Cooper and Bear, 2012). Thus, we tested whether there were any differences in LTP induced using a protocol that would normally induce only E-LTP (Frey and Morris, 1997) or a moderate frequency $(10 \mathrm{~Hz})$ that normally induces little to no change in synaptic strength (Dudek and Bear, 1992). We found no significant difference between genotypes using these induction protocols. These data suggest that Arc is not required for CA1 LTP in hippocampal slices.

\section{Arc does not regulate LTP in the DG in vivo}

Previous studies found that Arc antisense ODNs affected in vivo LTP in the DG of rats (Guzowski et al., 2000; Messaoudi et al., 2007). We investigated the role of Arc in LTP in vivo in the DG of Arc ${ }^{\text {GFP/GFP }}$ animals. We found that the magnitude of LTP induction was significantly greater in the first 5 min poststimulation, but there was no significant difference between Arc ${ }^{\text {GFP/GFP }}$ and WT animals $3 \mathrm{~h}$ after induction. Previous studies found that the magnitude of LTP induction was initially enhanced in $\mathrm{Arc}^{-1-}$, but the maintenance was significantly attenuated (Plath et al., 2006). Our experiments used the same induction protocol in the DG, but were undertaken in isoflurane-anesthetized mice, rather than urethane anesthesia (Plath et al., 2006). It is possible that maintenance of LTP in the DG is differentially affected by either the anesthetic regime or Arc knockout strategy. A different study infused Arc antisense ODNs into the DG of rats $1.5 \mathrm{~h}$ before LTP induction, which had no effect on the initial LTP 
magnitude but significantly attenuated LTP magnitude $5 \mathrm{~d}$ poststimulation (Guzowski et al., 2000). Our studies do not rule out a role for Arc in the maintenance of LTP over days. Another study found that when Arc antisense ODNs were injected into the DG in vivo 15 min post-LTP induction, synaptic strength transiently decreased to near baseline for $\sim 3 \mathrm{~h}$ before it recovered to normal levels of potentiation (Messaoudi et al., 2007) indicating that the ODNs did not alter the persistence of LTP. Further, when ODNs were injected $2 \mathrm{~h}$ post-LTP induction, synaptic strength also decreased to near baseline, although recordings were not made $3 \mathrm{~h}$ later to see whether potentiation recovered (Messaoudi et al., 2007). In germline Arc KO mice, it is possible that there is compensation by an unknown protein that performs a similar function in LTP, which still implies that Arc is not essential for LTP.

\section{How does arc mediate long-term memory?}

Although LTP has long been associated with long-term memory, and long-term memory is critically dependent on Arc expression (Guzowski et al., 2000; Plath et al., 2006; Ploski et al., 2008), the potentiation of synapses is not the only critical process (Zhang and Linden, 2003; Mozzachiodi and Byrne, 2010; Kyrke-Smith and Williams, 2018; Lisman et al., 2018; Abraham et al., 2019). Similarly, in response to stimulation paradigms that induce LTP, there are widespread changes aside from LTP, such as heterosynaptic depression, changes to intrinsic excitability and the regulation of gene expression, protein synthesis, and signaling pathways (Lynch et al., 1977; Andersen et al., 1980; Abraham and Goddard, 1983; Lopez de Armentia et al., 2007; Caroni et al., 2014; Kyrke-Smith and Williams, 2018). We posit that Arc expression driven by LTP induction may contribute to non-LTP plasticity that serves a homeostatic function to maintain overall network stability such as heterosynaptic LTD or synaptic downscaling (Shepherd and Bear, 2011). A loss of these forms of synaptic weakening in the germline Arc KO mice could account for the exaggerated LTP induction that we and others (Plath et al., 2006) have observed. This idea is also consistent with the finding that Arc interacts with CaMKII $\beta$ at inactive synapses to remove AMPARs and decrease synaptic strength (Okuno et al., 2012; ElBoustani et al., 2018). Similarly, Arc may eliminate small mushroom spines after learning (Nakayama et al., 2015), although it is unclear if this occurs through heterosynaptic LTD. The net result of these processes would enhance the signal-to-noise ratio of the potentiated synapses, while still maintaining a normal dynamic range of plasticity and neuronal activity, which may be critical for long-term memory. Similarly, Arc-dependent homeostatic scaling (Shepherd et al., 2006, Korb et al., 2013) may also be important for stabilizing memory engrams. Arc-dependent plasticity mechanisms are also important for normal experiencedependent sculpting of circuits during development (Jenks et al., 2017; Jenks and Shepherd, 2020), which may be critical for normal learning and memory later in adulthood (Gao et al., 2018).

Epigenetic mechanisms are also important for long-term memory and L-LTP (Korzus et al., 2004; Levenson et al., 2004; Gräff et al., 2011; Gräff et al., 2014; Jarome and Lubin, 2014). Interestingly, Arc has been shown to localize in the nucleus and interact with histone acetyltransferase Tip60, leading to increased acH4K12 (Wee et al., 2014), which is associated with increased gene expression. Arc is also expressed in promyelocytic leukemia nuclear bodies in the nucleus, where it may regulate the expression of plasticity-related genes (Korb et al., 2013). We recently showed that Arc can form virus-like capsids that can transfer RNA cell to cell (Pastuzyn et al., 2018). Although the role of intercellular Arc in plasticity and memory remains to be determined, it is another mechanism that may underlie long-term memory independent of LTP. Thus, many possibilities exist to explain how Arc can play a critical role in long-term memory without being necessary for L-LTP maintenance. Determining the precise molecular processes governed by Arc will likely provide great insight into the consolidation of memory.

\section{References}

Abraham WC, Bear MF (1996) Metaplasticity: the plasticity of synaptic plasticity. Trends in Neurosciences 19:126-130.

Abraham WC, Goddard GV (1983) Asymmetric relationships between homosynaptic long-term potentiation and heterosynaptic long-term depression. Nature 305:717-719.

Abraham WC, Jones OD, Glanzman DL (2019) Is plasticity of synapses the mechanism of long-term memory storage? NPJ Sci Learn 4:9.

Abraham WC, Williams JM (2003) Properties and mechanisms of LTP maintenance. Neuroscientist 9:463-474.

Alberini CM (1999) Genes to remember. J Ex Biol 202:2887-2891.

Alberini CM (2009) Transcription factors in long-term memory and synaptic plasticity. Physiol Rev 89:121-145.

Andersen P, Sundberg SH, Sveen O, Swann JW, Wigström H (1980) Possible mechanisms for long-lasting potentiation of synaptic transmission in hippocampal slices from guinea-pigs. J Physiol 302:463-482.

Arendt KL, Sarti F, Chen L (2013) Chronic inactivation of a neural circuit enhances LTP by inducing silent synapse formation. J Neurosci 33:20872096.

Bienenstock EL, Cooper LN, Munro PW (1982) Theory for the development of neuron selectivity: orientation specificity and binocular interaction in visual cortex. J Neurosci 2:32-48.

Bliss TV, Collingridge GL (1993) A synaptic model of memory: long-term potentiation in the hippocampus. Nature 361:31-39.

Bloomer WAC, VanDongen HMA, VanDongen AMJ (2007) Activity-regulated cytoskeleton-associated protein Arc/Arg3.1 binds to spectrin and associates with nuclear promyelocytic leukemia (PML) bodies. Brain Res 1153:20-33.

Bramham CR, Alme MN, Bittins M, Kuipers SD, Nair RR, Pai B, Panja D, Schubert M, Soule J, Tiron A, Wibrand K (2010) The Arc of synaptic memory. Exp Brain Res 200:125-140.

Caroni P, Chowdhury A, andLahr M (2014) Synapse rearrangements upon learning: from divergent-sparse connectivity to dedicated sub-circuits. Trends Neurosci 37:604-614.

Chen JY, Campos CA, Jarvie BC, Palmiter RD (2018) Parabrachial CGRP neurons establish and sustain aversive taste memories. Neuron 100:891899.e5.

Choi J-H, Sim S-E, Kim J-i, Choi DI, Oh J, Ye S, Lee J, Kim T, Ko H-G, Lim C-S, Kaang B-K (2018) Interregional synaptic maps among engram cells underlie memory formation. Science 360:430-435.

Chowdhury S, Shepherd JD, Okuno H, Lyford G, Petralia RS, Plath N, Kuhl D, Huganir RL, Worley PF (2006) Arc/Arg3.1 interacts with the endocytic machinery to regulate AMPA receptor trafficking. Neuron 52:445459.

Cooper LN, Bear MF (2012) The BCM theory of synapse modification at 30: interaction of theory with experiment. Nat Rev Neurosci 13:798-810.

DaSilva LLP, Wall MJ, P. de Almeida L, Wauters SC, Januário YC, Müller J, Corrêa SAL (2016) Activity-regulated cytoskeleton-associated protein controls AMPAR endocytosis through a direct interaction with clathrinadaptor protein 2. eNeuro 3:ENEURO.0144-15.2016.

Dudek SM, Bear MF (1992) Homosynaptic long-term depression in area CA1 of hippocampus and effects of N-methyl-D-aspartate receptor blockade. Proc Natl Acad Sci U S A 89:4363-4367.

El-Boustani S, Ip JPK, Breton-Provencher V, Knott GW, Okuno H, Bito H, Sur M (2018) Locally coordinated synaptic plasticity of visual cortex neurons in vivo. Science 360:1349-1354.

Frey U, Morris RGM (1997) Synaptic tagging and long-term potentiation. Nature 385:533-536.

Gao X, Castro-Gomez S, Grendel J, Graf S, Süsens U, Binkle L, Mensching D, Isbrandt D, Kuhl D, Ohana O (2018) Arc/Arg3.1 mediates a critical period for spatial learning and hippocampal networks. Proc Natl Acad Sci U S A 115:12531-12536. 
Gao X, Grendel J, Muhia M, Castro-Gomez S, Süsens U, Isbrandt D, Kneussel M, Kuhl D, Ohana O (2019) Disturbed prefrontal cortex activity in the absence of schizophrenia-like behavioral dysfunction in Arc/ Arg3.1 Deficient Mice. J Neurosci 39:8149-8163.

Goelet P, Castellucci VF, Schacher S, Kandel ER (1986) The long and the short of long-term memory-a molecular framework. Nature 322:419422.

Gräff J, Kim D, Dobbin MM, Tsai LH (2011) Epigenetic regulation of gene expression in physiological and pathological brain processes. Physiol Rev 91:603-649.

Gräff J, Joseph NF, Horn ME, Samiei A, Meng J, Seo J, Rei D, Bero AW, Phan TX, Wagner F, Holson E, Xu J, Sun J, Neve RL, Mach RH, Haggarty SJ, Tsai LH (2014) Epigenetic priming of memory updating during reconsolidation to attenuate remote fear memories. Cell 156:261276.

Guzowski JF, Lyford GL, Stevenson GD, Houston FP, McGaugh JL, Worley PF, Barnes CA (2000) Inhibition of activity-dependent arc protein expression in the rat hippocampus impairs the maintenance of long-term potentiation and the consolidation of long-term memory. J Neurosci 20:3993-4001

Harris KM, Jensen FE, Tsao B (1992) Three-dimensional structure of dendritic spines and synapses in rat hippocampus (CA1) at postnatal day 15 and adult ages: implications for the maturation of synaptic physiology and long-term potentiation. J Neurosci 12:2685-2705.

Jarome TJ, Lubin FD (2014) Epigenetic mechanisms of memory formation and reconsolidation. Neurobiol Learn Mem 115:116-127.

Jedlicka P (2002) Synaptic plasticity, metaplasticity and BCM theory. Bratisl Lek Listy 103:137-143.

Jenks KR, Shepherd JD (2020) Experience-dependent development and maintenance of binocular neurons in the mouse visual cortex. Cell Rep 30:1982-1994.e4.

Jenks KR, Kim T, Pastuzyn ED, Okuno H, Taibi AV, Bito H, Bear MF, Shepherd JD (2017) Arc restores juvenile plasticity in adult mouse visual cortex. Proc Natl Acad Sci U S A 114:9182-9187.

Kandel ER, Dudai Y, Mayford MR (2014) The molecular and systems biology of memory. Cell 157:163-186.

Korb E, Wilkinson CL, Delgado RN, Lovero KL, Finkbeiner S (2013) Arc in the nucleus regulates PML-dependent GluA1 transcription and homeostatic plasticity. Nat Neurosci 16:874-883.

Korzus E, Rosenfeld MG, Mayford M (2004) CBP histone acetyltransferase activity is a critical component of memory consolidation. Neuron 42:961-972.

Kuipers SD, Trentani A, Tiron A, Mao X, Kuhl D, Bramham CR (2016) BDNF-induced LTP is associated with rapid Arc/Arg3.1-dependent enhancement in adult hippocampal neurogenesis. Sci Rep 6:2122221222.

Kyrke-Smith M, Williams M (2018) Bridging synaptic and epigenetic maintenance mechanisms of the engram. Front Mol Neurosci 11:369.

Larson J, Wong D, Lynch G (1986) Patterned stimulation at the theta frequency is optimal for the induction of hippocampal long-term potentiation. Brain Res 368:347-350.

Levenson JM, O'Riordan KJ, Brown KD, Trinh MA, Molfese DL, Sweatt JD (2004) Regulation of histone acetylation during memory formation in the hippocampus. J Biol Chem 279:40545-40559.

Link W, Konietzko U, Kauselmann G, Krug M, Schwanke B, Frey U, Kuhl D (1995) Somatodendritic expression of an immediate early gene is regulated by synaptic activity. Proc Natl Acad Sci U S A 92:5734-5738.

Lisman J, Cooper K, Sehgal M, Silva AJ (2018) Memory formation depends on both synapse-specific modifications of synaptic strength and cell-specific increases in excitability. Nat Neurosci 21:309-314

Lopez de Armentia M, Jancic D, Olivares R, Alarcon JM, Kandel ER, Barco A (2007) cAMP response element-binding protein-mediated gene expression increases the intrinsic excitability of CA1 pyramidal neurons. J Neurosci 27:13909-13918.

Lyford GL, Yamagata K, Kaufmann WE, Barnes CA, Sanders LK, Copeland NG, Gilbert DJ, Jenkins NA, Lanahan AA, Worley PF (1995) Arc, a growth factor and activity-regulated gene, encodes a novel cytoskeletonassociated protein that is enriched in neuronal dendrites. Neuron 14:433-445.

Lynch GS, Dunwiddie T, Gribkoff V (1977) Heterosynaptic depression: a postsynaptic correlate of long-term potentiation. Nature 266:737-739.
Managò F, Mereu M, Mastwal S, Mastrogiacomo R, Scheggia D, Emanuele M, De Luca MA, Weinberger DR, Wang KH, Papaleo F (2016) Genetic disruption of Arc/Arg3.1 in mice causes alterations in dopamine and neurobehavioral phenotypes related to schizophrenia. Cell Rep 16:21162128.

Matsuzaki M, Honkura N, Ellis-Davies GC, Kasai H (2004) Structural basis of long-term potentiation in single dendritic spines. Nature 429:761-766.

McCurry CL, Shepherd JD, Tropea D, Wang KH, Bear MF, Sur M (2010) Loss of Arc renders the visual cortex impervious to the effects of sensory experience or deprivation. Nat Neurosci 13:450-457.

Messaoudi E, Kanhema T, Soulé J, Tiron A, Dagyte G, Da Silva B, Bramham CR (2007) Sustained Arc/Arg3.1 synthesis controls long-term potentiation consolidation through regulation of local actin polymerization in the dentate gyrus in vivo. J Neurosci 27:10445-10455.

Moga DE, Calhoun ME, Chowdhury A, Worley P, Morrison JH, Shapiro ML (2004) Activity-regulated cytoskeletal-associated protein is localized to recently activated excitatory synapses. Neuroscience 125:7-11.

Mozzachiodi R, Byrne JH (2010) More than synaptic plasticity: role of nonsynaptic plasticity in learning and memory. Trends Neurosci 33:17-26.

Nabavi S, Fox R, Proulx CD, Lin JY, Tsien RY, Malinow R (2014) Engineering a memory with LTD and LTP. Nature 511:348-352.

Nair RR, Patil S, Tiron A, Kanhema T, Panja D, Schiro L, Parobczak K, Wilczynski G, Bramham CR (2017) Dynamic arc SUMOylation and selective interaction with F-Actin-binding protein drebrin A in LTP consolidation in vivo. Front Synaptic Neurosci 9:8.

Nakayama D, Iwata H, Teshirogi C, Ikegaya Y, Matsuki N, Nomura H (2015) Long-delayed expression of the immediate early gene Arc/Arg3.1 refines neuronal circuits to perpetuate fear memory. J Neurosci 35:819-830.

Nguyen PV, Abel T, Kandel ER (1994) Requirement of a critical period of transcription for induction of a late phase of LTP. Science 265:11041107.

Okuno H, Akashi K, Ishii Y, Yagishita-Kyo N, Suzuki K, Nonaka M, Kawashima T, Fujii $H$, Takemoto-Kimura $S$, Abe $M$, Natsume $R$, Chowdhury S, Sakimura K, Worley PF, Bito H (2012) Inverse synaptic tagging of inactive synapses via dynamic interaction of Arc/Arg3.1 with CaMKII $\beta$. Cell 149:886-898.

Pastuzyn ED, Day CE, Kearns RB, Kyrke-Smith M, Taibi AV, McCormick J, Yoder N, Belnap DM, Erlendsson S, Morado DR, Briggs JAG, Feschotte C, Shepherd JD (2018) The neuronal gene arc encodes a repurposed retrotransposon gag protein that mediates intercellular RNA transfer. Cell 172:275-288.e18.

Peebles CL, Thwin JYMT, Palop JJ, Noebels JL, Finkbeiner S (2010). Arc regulates spine morphology and maintains network stability in vivo. Proc Natl Acad Sci U S A 107:18173-18178.

Pham CT, MacIvor DM, Hug BA, Heusel JW, Ley TJ (1996) Long-range disruption of gene expression by a selectable marker cassette. Proc Natl Acad Sci U S A 93:13090-13095.

Plath N, Ohana O, Dammermann B, Errington ML, Schmitz D, Gross C, Mao X, Engelsberg A, Mahlke C, Welzl H, Kobalz U, Stawrakakis A, Fernandez E, Waltereit R, Bick-Sander A, Therstappen E, Cooke SF, Blanquet V, Wurst W, Salmen B, et al (2006) Arc/Arg3.1 is essential for the consolidation of synaptic plasticity and memories. Neuron 52:437444.

Ploski JE, Pierre VJ, Smucny J, Park K, Monsey MS, Overeem KA, Schafe GE (2008) The activity-regulated cytoskeletal-associated protein (Arc/ Arg3.1) is required for memory consolidation of pavlovian fear conditioning in the lateral amygdala. J Neurosci 28:12383-12395.

Poo M-M, Pignatelli M, Ryan TJ, Tonegawa S, Bonhoeffer T, Martin KC, Rudenko A, Tsai L-H, Tsien RW, Fishell G, Mullins C, Gonçalves JT, Shtrahman M, Johnston ST, Gage FH, Dan Y, Long J, Buzsáki G, Stevens C (2016) What is memory? The present state of the engram. BMC Biol 14:40.

Reymann KG, Malisch R, Schulzeck K, Brödemann R, Ott T, Matthies H (1985) The duration of long-term potentiation in the CA1 region of the hippocampal slice preparation. Brain Res Bull 15:249-255.

Rial Verde EM, Lee-Osbourne J, Worley PF, Malinow R, Cline HT (2006) Increased expression of the immediate-early gene arc/arg3.1 reduces AMPA receptor-mediated synaptic transmission. Neuron 52:461-474.

Rioult-Pedotti MS, Donoghue JP, Dunaevsky A (2007) Plasticity of the synaptic modification range. J Neurophysiol 98:3688-3695.

Rodríguez JJ, Davies HA, Silva AT, De Souza IEJ, Peddie CJ, Colyer FM, Lancashire CL, Fine A, Errington ML, Bliss TVP, Stewart MG (2005) 
Long-term potentiation in the rat dentate gyrus is associated with enhanced Arc/Arg3.1 protein expression in spines, dendrites and glia. Eur J Neurosci 21:2384-2396.

Scacheri PC, Crabtree JS, Novotny EA, Garrett-Beal L, Chen A, Edgemon KA, Marx SJ, Spiegel AM, Chandrasekharappa SC, Collins FS (2001) Bidirectional transcriptional activity of PGK-neomycin and unexpected embryonic lethality in heterozygote chimeric knockout mice. Genesis 30:259-263.

Shepherd JD, Bear MF (2011) New views of Arc, a master regulator of synaptic plasticity. Nat Neurosci 14:279-284.

Shepherd JD, Rumbaugh G, Wu J, Chowdhury S, Plath N, Kuhl D, Huganir RL, Worley PF (2006) Arc/Arg3.1 mediates homeostatic synaptic scaling of AMPA receptors. Neuron 52:475-484.

Spacek J, Harris KM (1997) Three-dimensional organization of smooth endoplasmic reticulum in hippocampal CA1 dendrites and dendritic spines of the immature and mature rat. J Neurosci 17:190-203.

Steward O, Wallace CS, Lyford GL, Worley PF (1998) Synaptic activation causes the mRNA for the IEG Arc to localize selectively near activated postsynaptic sites on dendrites. Neuron 21:741-751.

Takeuchi T, Duszkiewicz AJ, Morris RGM (2014) The synaptic plasticity and memory hypothesis: encoding, storage and persistence. Phil Trans R Soc B 369:20130288.

Thomas MJ, Watabe AM, Moody TD, Makhinson M, O’Dell TJ (1998) Postsynaptic complex spike bursting enables the induction of LTP by theta frequency synaptic stimulation. J Neurosci 18:7118-7126.

Volk LJ, Bachman JL, Johnson R, Yu Y, Huganir RL (2013) PKM- $\zeta$ is not required for hippocampal synaptic plasticity, learning and memory. Nature 493:420-423.
Wang H, Ardiles AO, Yang S, Tran T, Posada-Duque R, Valdivia G, Baek M, Chuang Y-A, Palacios AG, Gallagher M, Worley P, Kirkwood A (2016) Metabotropic glutamate receptors induce a form of LTP controlled by translation and arc signaling in the hippocampus. J Neurosci 36:17231729.

Wang KH, Majewska A, Schummers J, Farley B, Hu C, Sur M, Tonegawa S (2006) In vivo two-photon imaging reveals a role of Arc in enhancing orientation specificity in visual cortex. Cell 126:389-402.

Waung MW, Pfeiffer BE, Nosyreva ED, Ronesi JA, Huber KM (2008) Rapid translation of Arc/Arg3.1 selectively mediates mGluR-dependent LTD through persistent increases in AMPAR endocytosis rate. Neuron 59:8497.

Wee CL, Teo S, Oey NE, Wright GD, VanDongen HM, VanDongen AM (2014) Nuclear arc interacts with the histone acetyltransferase Tip60 to modify H4K12 acetylation. eNeuro 1:ENEURO.0019-14.2014.

Whitlock JR, Heynen AJ, Shuler MG, Bear MF (2006) Learning induces long-term potentiation in the hippocampus. Science 313:1093-1097.

Yin Y, Edelman GM, and Vanderklish PW (2002) The brain-derived neurotrophic factor enhances synthesis of Arc in synaptoneurosomes. Proc Natl Acad Sci U S A 99:2368-2373.

Ying SW, Futter M, Rosenblum K, Webber MJ, Hunt SP, Bliss TV, Bramham CR (2002) Brain-derived neurotrophic factor induces long-term potentiation in intact adult hippocampus: requirement for ERK activation coupled to CREB and upregulation of Arc synthesis. J Neurosci 22:15321540 .

Zhang W, Linden DJ (2003) The other side of the engram: experience-driven changes in neuronal intrinsic excitability. Nat Rev Neurosci 4:885-900. 